\title{
Research Regarding the Influence of some Technological Factors on Sorghum Capacity to Form Shoots, under the Center of Moldavia Conditions
}

\author{
Simona - Florina POCHIŞCANU ${ }^{1 *}$, Teodor ROBU ${ }^{1}$, Margareta NAIE ${ }^{1}$ and Elena TROTUS ${ }^{2}$ \\ ${ }^{1}$ University of Agricultural Science and Veterinary Medicine of Iaşi, \\ 3 Mihail Sadoveanu Alley, Iaşi, 700490, Romania \\ ${ }^{2}$ Agricultural Research and Devolopment Station Secuieni, Neamț, \\ 377 Principală Street, Secuieni, Neamț, Romania \\ *Corresponding author: simonapochi@yahoo.com
}

Bulletin USAMV series Agriculture 72(2)/2015

Print ISSN 1843-5246; Electronic ISSN 1843-5386

DOI 10.15835/buasvmcn-agr: 11407

\begin{abstract}
Sorghum can be an excellent source of starch, protein, sugar, fiber, being cheaper than corn, because the costs/ ha are lower than corn. It has a great development due to its use in food industry, especially in semi arid areas of the world where the climatic conditions offer limited conditions for agriculture. In this paper, we managed to prove how important is the proper fertilization with nitrogen and phosphorus in forming the number of shoots/field and how important is the ensuring of an optimal seeding density on the formation of main plant in the sorghum field.

Considering the importance of plants number in field, the main objective of the researches conducted during 2013 - 2014, was to study the sprouting ability of sorghum plants and the influence of some technological factors on it, knowing their direct influence in forming the field and indirect influence on grain production. In the experimental field of Agricultural Research - Development Station Secuieni, we placed an experience of $3 \mathrm{x} 4$ $\mathrm{x} 4$ type, where we study at three hybrids of sorghum for grain, the influence of sowing density and nitrogen and phosphorus fertilization on Sorghum bicolor L. plantlets ability to sprout.

The obtained results highlight the fact that the nitrogen and phosphorus fertilization contribute to the increasing of the shoots number/plant, but the sowing density negatively influence their formation. The correlation between nitrogen and phosphorus fertilization and the shoots number/ha was direct, the correlation coefficients were statistically ensured and interpreted as very significant, while that between sowing density and shoots number/ha was indirect, in this case, the correlation coefficients were interpreted as negative very significant.
\end{abstract}

Keywords: density, mineral fertilization, shoots, plants, sorghum.

\section{INTRODUCTION}

Sorghum (Sorghum bicolor L. Moench) is an important cereal in the world, the fourth major cereal in terms of production, and fifth in acreage following wheat, rice, maize and barley.

It has a great development and because its use in the alimentation especially in the semi-arid areas of the world where the climatic conditions gives limited conditions for agriculture. Such situations predominantly in Africa, Asia and Latin America, which are frequently drought-prone. India grows the largest acreage of sorghum in the world followed by Nigeria and Sudan, and produces the second largest tonnage after the US (FAO, 1995; ICRISAT, 2004; Nadia et al., 2009).

Sorghum can be an excellent source of starch, protein, sugar, fiber, being cheaper than corn, because the cost/ha are lower than the corn (Claver et al., 2010; Shinde, 2005; Singh et al., 2009; Singh and Sandhu., 2007). The climatic evolution towards heating and aridization in the Balkan area, where Romania is also found, compels to a reconsideration of the sorghum as: alimentary cereal, fodder plant, technical plant (stationary and 
textile celluloses, plastic material), the industry of construction materials and the handicraft industry (brushes of domestic and industrial use, brooms, nettings) (Volf, 2009).Improvement of some technology links of cultivation of sorghum sequences is a matter of great importance for our country, in order to obtain high yields for providing the necessary food, feed feedstock in the production of bioethanol - considered a fuel of the future.

\section{MATERIALS AND METHODS}

To clarify the issues proposed, during 2013 - 2014, was organized a trifactorial experience, in which were applied different technological sequences at certain genotypes of sorghum.
The placement of the experiences wasmade in the experimental field of the Agricultural Research - Development Station - Secuieni, Neamt, after the subdivided parcels method, in three repetitions.

The placement was made on a typical faeoziom soil type, middle texture, acid: $\mathrm{pH}_{\mathrm{H} 2} \mathrm{O}-$ 5.98, characterized as: well stocked in phosphorus (77.6 ppm $\mathrm{P}_{\mathrm{AL}}$ ), Ca (13.6 meq/100 g soil Ca) and $\mathrm{Mg}$ (1.8 meq/100 g soil $\mathrm{Mg}$ ); middle stocked in active humus $(1.88 \%)$ and nitrogen (16.2 ppm N-NO $)$ and poorly stocked in potassium (124.6 ppm $\mathrm{K}_{2} \mathrm{O}$ ).

The technological parameters concerned in this paper are sowing density and fertilization, because it is well known that the sowing density, present importance due to its positive correlation with the number of plants present which forms

Tab. 1. The influence of the interaction of the studied factors on the ratio between the number of main plants/ ha and the number of shoots/ha at Sorghum bicolor L., 2013

\begin{tabular}{|c|c|c|c|c|c|c|c|c|}
\hline \multirow{3}{*}{ Fertilization } & \multirow{3}{*}{ Hybrid } & \multirow{3}{*}{$\begin{array}{l}\text { Density } \\
\text { (g.s./ha) }\end{array}$} & \multirow{3}{*}{$\begin{array}{l}\text { Total plants } \\
\text { at harvest } \\
\text { (thousands) }\end{array}$} & \multicolumn{5}{|c|}{ Of which: } \\
\hline & & & & \multicolumn{2}{|c|}{ Main plants } & \multicolumn{3}{|c|}{ Shoots } \\
\hline & & & & thousands & $\%$ & thousands & $\%$ & $\begin{array}{c}\text { Average } \\
\text { no./pl }\end{array}$ \\
\hline \multirow{12}{*}{$\mathrm{N}_{0} \mathrm{P}_{0}$} & \multirow{4}{*}{ Fundulea 32} & 150000 & 233 & 108 & 46 & 125 & 54 & 1.16 \\
\hline & & 200000 & 239 & 147 & 62 & 92 & 38 & 0.63 \\
\hline & & 250000 & 272 & 193 & 71 & 79 & 29 & 0.41 \\
\hline & & 300000 & 297 & 232 & 78 & 65 & 22 & 0.28 \\
\hline & \multirow{4}{*}{ Alize } & 150000 & 233 & 114 & 49 & 119 & 51 & 1.04 \\
\hline & & 200000 & 246 & 156 & 63 & 90 & 37 & 0.58 \\
\hline & & 250000 & 270 & 199 & 74 & 71 & 26 & 0.36 \\
\hline & & 300000 & 303 & 241 & 80 & 62 & 20 & 0.26 \\
\hline & \multirow{4}{*}{ Armida } & 150000 & 234 & 120 & 51 & 114 & 49 & 0.95 \\
\hline & & 200000 & 245 & 161 & 66 & 84 & 34 & 0.52 \\
\hline & & 250000 & 272 & 202 & 74 & 70 & 26 & 0.35 \\
\hline & & 300000 & 304 & 243 & 80 & 61 & 20 & 0.25 \\
\hline \multirow{12}{*}{$\mathrm{N}_{40} \mathrm{P}_{40}$} & \multirow{4}{*}{ Fundulea 32} & 150000 & 261 & 125 & 48 & 136 & 52 & 1.09 \\
\hline & & 200000 & 263 & 162 & 62 & 101 & 38 & 0.62 \\
\hline & & 250000 & 294 & 206 & 70 & 88 & 30 & 0.43 \\
\hline & & 300000 & 330 & 258 & 78 & 72 & 22 & 0.28 \\
\hline & \multirow{4}{*}{ Alize } & 150000 & 261 & 130 & 50 & 131 & 50 & 1.01 \\
\hline & & 200000 & 263 & 166 & 63 & 97 & 37 & 0.58 \\
\hline & & 250000 & 300 & 215 & 72 & 85 & 28 & 0.40 \\
\hline & & 300000 & 334 & 267 & 80 & 67 & 20 & 0.25 \\
\hline & \multirow{4}{*}{ Armida } & 150000 & 261 & 134 & 51 & 127 & 49 & 0.95 \\
\hline & & 200000 & 270 & 178 & 66 & 92 & 34 & 0.52 \\
\hline & & 250000 & 303 & 222 & 73 & 81 & 27 & 0.36 \\
\hline & & 300000 & 341 & 276 & 81 & 65 & 19 & 0.24 \\
\hline
\end{tabular}




\begin{tabular}{|c|c|c|c|c|c|c|c|c|}
\hline \multirow{12}{*}{$\mathrm{N}_{80} \mathrm{P}_{80}$} & \multirow{4}{*}{ Fundulea 32} & 150000 & 272 & 128 & 47 & 144 & 53 & 1.13 \\
\hline & & 200000 & 283 & 171 & 60 & 112 & 40 & 0.65 \\
\hline & & 250000 & 312 & 215 & 69 & 97 & 31 & 0.45 \\
\hline & & 300000 & 354 & 264 & 75 & 90 & 25 & 0.34 \\
\hline & \multirow{4}{*}{ Alize } & 150000 & 270 & 132 & 49 & 138 & 51 & 1.05 \\
\hline & & 200000 & 283 & 178 & 63 & 105 & 37 & 0.59 \\
\hline & & 250000 & 318 & 227 & 71 & 91 & 29 & 0.40 \\
\hline & & 300000 & 360 & 276 & 77 & 84 & 23 & 0.30 \\
\hline & \multirow{4}{*}{ Armida } & 150000 & 269 & 134 & 50 & 135 & 50 & 1.01 \\
\hline & & 200000 & 282 & 181 & 64 & 101 & 36 & 0.56 \\
\hline & & 250000 & 327 & 236 & 72 & 91 & 28 & 0.39 \\
\hline & & 300000 & 362 & 282 & 78 & 80 & 22 & 0.28 \\
\hline \multirow{12}{*}{$\mathrm{N}_{120} \mathrm{P}_{120}$} & \multirow{4}{*}{ Fundulea 32} & 150000 & 291 & 130 & 45 & 161 & 55 & 1.24 \\
\hline & & 200000 & 300 & 178 & 59 & 122 & 41 & 0.69 \\
\hline & & 250000 & 327 & 222 & 68 & 105 & 32 & 0.47 \\
\hline & & 300000 & 367 & 271 & 74 & 96 & 26 & 0.35 \\
\hline & \multirow{4}{*}{ Alize } & 150000 & 290 & 124 & 43 & 166 & 57 & 1.34 \\
\hline & & 200000 & 300 & 175 & 58 & 125 & 42 & 0.71 \\
\hline & & 250000 & 314 & 214 & 68 & 100 & 32 & 0.47 \\
\hline & & 300000 & 365 & 274 & 75 & 91 & 25 & 0.33 \\
\hline & \multirow{4}{*}{ Armida } & 150000 & 277 & 135 & 49 & 142 & 51 & 1.05 \\
\hline & & 200000 & 307 & 186 & 61 & 121 & 39 & 0.65 \\
\hline & & 250000 & 330 & 234 & 71 & 96 & 29 & 0.41 \\
\hline & & 300000 & 362 & 282 & 78 & 80 & 22 & 0.28 \\
\hline
\end{tabular}

the plants density in field and at harvesting, and, the mineral fertilizers are of special importance in increasing production at grain sorghum.

The experimental factors studied in the experimental field were of the $\mathrm{A} \times \mathrm{B} \times \mathrm{C}$ type, where: A factor was represented by the hybrid ( $a_{1}$ - Fundulea 32, $a_{2}-$ Alize, $a_{3}-$ Armida), $B$ factor, by the insured sowing density $\left(b_{1}-150000\right.$ germinate seeds $/ \mathrm{ha}, \mathrm{b}_{2}-200000$ germinate seeds /ha, $b_{3}-250000$ germinate seeds $/$ ha, $b_{4}-300000$ germinate seeds $/ \mathrm{ha}$ ), and $\mathrm{C}$ factor was represented by the nitrogen and phosphorus fertilization $\left(\mathrm{c}_{1}-\right.$ unfertilized, $\mathrm{c}_{2}-\mathrm{N}_{40} \mathrm{P}_{40}, \mathrm{C}_{3}-\mathrm{N}_{80} \mathrm{P}_{80}, \mathrm{c}_{4}-\mathrm{N}_{120} \mathrm{P}_{120}$ ). The experiences sowing was done on the same day (3.05), at a temperature in soil of $12^{\circ} \mathrm{C}$, at a depth of $3-4 \mathrm{~cm}$, and the application of the chemical fertilizers was done manually at the seedbed preparation. Previous plant was soybeans.To describe the degree of linear association between technological factors studied and the number of shoots in the field, we calculated the Pearson correlation coefficient ( $\mathrm{r}$ ), which takes values between +1 and -1 , the positive values showing a positive correlation and the negative ones showing negative correlations.

\section{RESULTS AND DISCUSSION}

Due to the made researches it was found that the experimented technological sequences had major influences on the plant phenological characters.

In the first year of experimentation (2013), it was observed that along with increasing the doses of nitrogen and phosphorus fertilizers increases and the number of shoots/ha, but increased the sowing densities determinated the increase of main palnts number/ha and the decrease of the shoots number/ha. The shoots number from field varied within very wide limits, between 61000 shoots/ha (Armida x 300000 g.s./ha x $\mathrm{N}_{0} \mathrm{P}_{0}$ ) and 166000 shoots/ha. The ratio between the number of main plants/ha and the number of shoots/plant revealed that the highest number of shoots/plant (1.34 shoots/plant) is realized at the variant sown with Alize hybrid at a density of 150000 g.s./ha and fertilized with $\mathrm{N}_{120} \mathrm{P}_{120}$, while the lowest $(0.24$ 
shoots/plant) at the interaction between Armida x 300000 g.s./ha x $\mathrm{N}_{40} \mathrm{P}_{40}$ (Tab 1).

From the results shown in Tab. 1 we can see that the nitrogen and phophorus fertilization has contributed to increasing the number of shoots/plant, but, the sowing density negatively influenced their formation.

The climatic conditions of the 2014 agricultural year negatively influenced the sorghum field formation by the appearance on May 25 of the hail phenomenon that caused the loss of $15 \%$ of the sorghum plantlets barely emerged.
The remaining plantlets after the incurred losses have covered the gaps by forming shoots, but of which few were productive (Tab. 2).

The results obtained in 2014 indicated the same thing as those achieved in the first year of experimentation, namely that the fertilization had positively influenced the shoots formation in field, and the sowing density had negatively influences on their formation (Tab. 2). The shoots were present in greater number in field due to the gaps caused by the hail. Thus, they ranged between 63000 shoots/ha (Armida x 300000 g.s./

Tab. 2. The influence of the interaction of the studied factors on the ratio between the number of main plants/ ha and the number of shoots/ha at Sorghum bicolor L., 2014

\begin{tabular}{|c|c|c|c|c|c|c|c|c|}
\hline \multirow{3}{*}{ Fertilization } & \multirow{3}{*}{ Hybrid } & \multirow{3}{*}{$\begin{array}{l}\text { Density } \\
\text { (g.s./ha) }\end{array}$} & \multirow{3}{*}{$\begin{array}{l}\text { Total plants } \\
\text { at harvest } \\
\text { (thousands) }\end{array}$} & \multicolumn{5}{|c|}{ Of which: } \\
\hline & & & & \multicolumn{2}{|c|}{ Main plants } & \multicolumn{3}{|c|}{ Shoots } \\
\hline & & & & thousands & $\%$ & thousands & $\%$ & $\begin{array}{c}\text { Average } \\
\text { no./pl }\end{array}$ \\
\hline \multirow{12}{*}{$\mathrm{N}_{0} \mathrm{P}_{0}$} & \multirow{4}{*}{ Fundulea 32} & 150000 & 226 & 96 & 42 & 130 & 58 & 1.35 \\
\hline & & 200000 & 222 & 126 & 57 & 96 & 43 & 0.76 \\
\hline & & 250000 & 247 & 165 & 67 & 82 & 33 & 0.50 \\
\hline & & 300000 & 266 & 199 & 75 & 67 & 25 & 0.34 \\
\hline & \multirow{4}{*}{ Alize } & 150000 & 224 & 99 & 44 & 125 & 56 & 1.26 \\
\hline & & 200000 & 231 & 134 & 58 & 97 & 42 & 0.72 \\
\hline & & 250000 & 246 & 171 & 70 & 75 & 30 & 0.44 \\
\hline & & 300000 & 272 & 208 & 76 & 64 & 24 & 0.31 \\
\hline & \multirow{4}{*}{ Armida } & 150000 & 224 & 103 & 46 & 121 & 54 & 1.17 \\
\hline & & 200000 & 225 & 134 & 60 & 91 & 40 & 0.68 \\
\hline & & 250000 & 249 & 175 & 70 & 74 & 30 & 0.42 \\
\hline & & 300000 & 273 & 210 & 77 & 63 & 23 & 0.30 \\
\hline \multirow{12}{*}{$\mathrm{N}_{40} \mathrm{P}_{40}$} & \multirow{4}{*}{ Fundulea 32} & 150000 & 244 & 100 & 41 & 144 & 59 & 1.44 \\
\hline & & 200000 & 248 & 141 & 57 & 107 & 43 & 0.76 \\
\hline & & 250000 & 267 & 174 & 65 & 93 & 35 & 0.53 \\
\hline & & 300000 & 296 & 221 & 75 & 75 & 25 & 0.34 \\
\hline & \multirow{4}{*}{ Alize } & 150000 & 252 & 106 & 42 & 146 & 58 & 1.38 \\
\hline & & 200000 & 242 & 140 & 58 & 102 & 42 & 0.73 \\
\hline & & 250000 & 272 & 182 & 67 & 90 & 33 & 0.49 \\
\hline & & 300000 & 299 & 228 & 76 & 71 & 24 & 0.31 \\
\hline & \multirow{4}{*}{ Armida } & 150000 & 245 & 112 & 46 & 133 & 54 & 1.19 \\
\hline & & 200000 & 249 & 153 & 61 & 96 & 39 & 0.63 \\
\hline & & 250000 & 275 & 190 & 69 & 85 & 31 & 0.45 \\
\hline & & 300000 & 302 & 234 & 77 & 68 & 23 & 0.29 \\
\hline \multirow{4}{*}{$\mathrm{N}_{80} \mathrm{P}_{80}$} & \multirow{4}{*}{ Fundulea 32} & 150000 & 258 & 106 & 41 & 152 & 59 & 1.43 \\
\hline & & 200000 & 264 & 146 & 55 & 118 & 45 & 0.81 \\
\hline & & 250000 & 286 & 184 & 64 & 102 & 36 & 0.55 \\
\hline & & 300000 & 317 & 225 & 71 & 92 & 29 & 0.41 \\
\hline
\end{tabular}


ha $x \mathrm{~N}_{0} \mathrm{P}_{0}$ ) and 175000 shoots/ha (Alize $\mathrm{x} 150000$ g.s./ha $\times \mathrm{N}_{120} \mathrm{P}_{120}$ ). The average number of shoots/ plant had varied in this year from 0.29 shoots/ plant (Armida x 300000 g.s./ha $\times \mathrm{N}_{40} \mathrm{P}_{40}$ ) and 1.68 shoots/ha (Alize x 150000 g.s./ha x $\mathrm{N}_{120} \mathrm{P}_{120}$ ) (Tab. 2).

The correlation between nitrogen and phosphorus fertilization and number of shoots/

Tab. 2. The influence of the interaction of the studied factors on the ratio between the number of main plants/ ha and the number of shoots/ha at Sorghum bicolor L., 2014 - continued

\begin{tabular}{|c|c|c|c|c|c|c|c|c|}
\hline \multirow{3}{*}{ Fertilization } & \multirow{3}{*}{ Hybrid } & \multirow{3}{*}{$\begin{array}{l}\text { Density } \\
\text { (g.s./ha) }\end{array}$} & \multirow{3}{*}{$\begin{array}{l}\text { Total plants } \\
\text { at harvest } \\
\text { (thousands) }\end{array}$} & \multicolumn{5}{|c|}{ Of which: } \\
\hline & & & & \multicolumn{2}{|c|}{ Main plants } & \multicolumn{3}{|c|}{ Shoots } \\
\hline & & & & thousands & $\%$ & thousands & $\%$ & $\begin{array}{c}\text { Average } \\
\text { no./pl }\end{array}$ \\
\hline \multirow{8}{*}{$\mathrm{N}_{80} \mathrm{P}_{80}$} & \multirow{4}{*}{ Alize } & 150000 & 253 & 109 & 43 & 144 & 57 & 1.32 \\
\hline & & 200000 & 260 & 152 & 58 & 108 & 42 & 0.71 \\
\hline & & 250000 & 287 & 192 & 67 & 95 & 33 & 0.49 \\
\hline & & 300000 & 323 & 236 & 73 & 87 & 27 & 0.37 \\
\hline & \multirow{4}{*}{ Armida } & 150000 & 254 & 112 & 44 & 142 & 56 & 1.27 \\
\hline & & 200000 & 261 & 156 & 60 & 105 & 40 & 0.67 \\
\hline & & 250000 & 299 & 204 & 68 & 95 & 32 & 0.47 \\
\hline & & 300000 & 323 & 241 & 75 & 82 & 25 & 0.34 \\
\hline \multirow{12}{*}{$\mathrm{N}_{120} \mathrm{P}_{120}$} & \multirow{4}{*}{ Fundulea 32} & 150000 & 278 & 108 & 39 & 170 & 61 & 1.57 \\
\hline & & 200000 & 280 & 152 & 54 & 128 & 46 & 0.84 \\
\hline & & 250000 & 299 & 190 & 64 & 109 & 36 & 0.57 \\
\hline & & 300000 & 331 & 232 & 70 & 99 & 30 & 0.43 \\
\hline & \multirow{4}{*}{ Alize } & 150000 & 279 & 104 & 37 & 175 & 63 & 1.68 \\
\hline & & 200000 & 279 & 150 & 54 & 129 & 46 & 0.86 \\
\hline & & 250000 & 285 & 182 & 64 & 103 & 36 & 0.57 \\
\hline & & 300000 & 330 & 236 & 72 & 94 & 28 & 0.40 \\
\hline & \multirow{4}{*}{ Armida } & 150000 & 262 & 112 & 43 & 150 & 57 & 1.34 \\
\hline & & 200000 & 283 & 156 & 55 & 127 & 45 & 0.81 \\
\hline & & 250000 & 294 & 194 & 66 & 100 & 34 & 0.52 \\
\hline & & 300000 & 325 & 241 & 74 & 84 & 26 & 0.35 \\
\hline
\end{tabular}

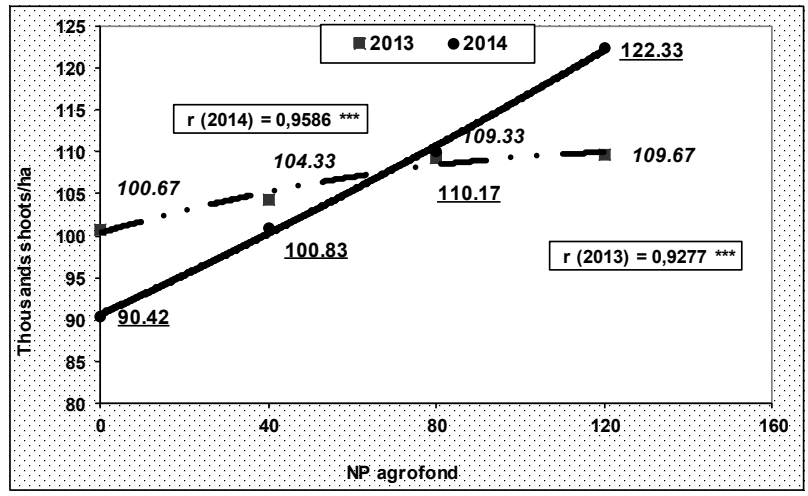

Fig. 1. The correlation between nitrogen and phosphorus fertilization and number of shoots/ ha at Sorghum bicolor L. (2013-2014)

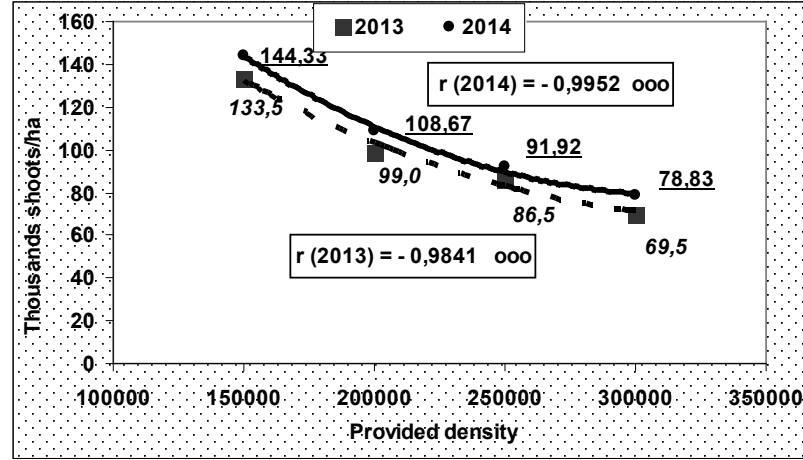

Fig. 2. The correlation between sowing density and the number of shoots/ha at Sorghum bicolor L. (2013-2014) 
ha was direct and very close, the correlation coefficients were statistically ensured and interpreted as very significant (Fig. 1.).

Regarding the correlation between sowing density and number of shoots/ha, this was indirect, and the correlation coefficients were statistically ensured and interpreted as negative very significant (ooo)(fig. 2.).

\section{CONCLUSION}

From the results obtained it emphasizes the idea that the studied technological factors had influenced the formation of the sorghum field, both in terms of the number of main plants, as well as the number of shoots.

The climatic conditions during the analyzed period were favorable to the sorghum crop, in 2013 and unfavorable in 2014. The formation of grain production in the second year of experimentation was conditioned by the formed shoots which have manged to cover the gaps caused by hail.

The fertilization with nitrogen and phosphoru had major influences on the number of shoots, the correlation between these two variables was direct and tight.

The sowing density positively influence the number of main plants, but negatively the number of shoots/field, between these two variables the correlation was indirect.

Acknowledgments. This paper was published under the frame of European Social Fund, Human Resources Development Operational Programme
2007-2013, project no. POSDRU/ 159/ 1.5/ S/ 132765 .

\section{REFERENCES}

1. Claver I P, Zhang H, Li Q Zhu K and Zhou H (2010). Impact of the Soak and the Malt on the Physicochemical Properties of the Sorghum Starches. International Journal of Molecular Sciences 11: 3002-3015, Doi: 10.3390/ ijms11083002.

2. FAO (1995). Sorghum and Millets in Human Nutrition. FAO Food and Nutrition Series, no. 27, ISBN 92-5-1033811.

3. International Crops Research Institute for the Semi-Arid Tropics (ICRISAT) (2004). Sorghum, a crop of substance. (In En.) Patancheru 502 324, Andhra Pradesh, India: International Crops Research Institute for the Semi-Arid Tropics, ISBN-92-9066-473-8.

4. Nadia B, Naïma B, Boubekeur N, Claude D, Mohamed M, Barbara R and Marianne S (2009). Physicochemical and functional properties of starches from sorghum cultivated in the Sahara of Algeria. Carbohydrate Polymers 78: 475480, Doi: 10.1016/j.carbpol.2009.05.010

5. Shinde VV (2005). Production kinetics and functional properties of carboxymethyl sorghum starch. Natural Product Radiance 4(6): 466-470.

6. Singh H, Singh Sodhi N and Singh N (2009). Structure and Functional Properties of Acid Thinned Sorghum Starch. International Journal of Food Properties 12: 713-725. Doi: 10.1080/10942910801995614

7. Singh N and Sandhu KS (2007). Some properties of corn starches II: Physicochemical, gelatinization, retrogradation, pasting and gel textural properties. Food Chemistry 101: 1499-1507. Doi: 10.1016/j.foodchem. 2006. 01.060

8. Volf M (2009). The improvement of the cultivation technology at fodder sorghum in the conditions of the Moldavian Plain. PhD Thesis. U.S.A.M.V. Iasi 